\title{
REKONSTRUKSI IDEOLOGI PANCASILA SEBAGAI SISTEM EKONOMI DALAM PERSPEKTIF WELFARE STATE
}

\author{
Achmad Hariri \\ Universitas Muhammadiyah Surabaya \\ Email : achmadhariri@fh.um-surabaya.ac.id
}

\begin{abstract}
Abstrak
Pancasila sebagai ideologi negara sudah semestinya menjadi katalisator dalam aspek kehidupan bernegara, terutama dalam soal ekonomi yang berkaitan langsung dengan hidup orang banyak, dalam Undang-Undang Dasar Negara Republik Indonesia Tahun 1945 (UUD Tahun 1945) Pasal 33 sudah jelas bahwa pasal tersebut menjadi ideologi sistem ekonomi Indonesia, namun dalam praksisnya tidak ada intstrumen yang jelas dalam menjalankan ideologi ekonomi tersebut, bahkan banyak Undang-undang yang bertentangan dengan pasal 33 UUD 1945 tersebut. Adapun tujuan dari penelitian ini adalah mengulas terkait dengan sistem ekonomi Pancasila untuk terwujudnya kesejahteraan. Sedangkan jenis penelitian ini adalah penelitian normatif dengan pendekatan perundangundangan (Statute Approach) dan pendekatan konsep (Conseptual Approach). Adapun hasil dari penelitian ini adalah Mengetengahkan sistem ekonomi pancasila menjadi keharusan ditengah pembangunan ekonomi yang tidak tentu, kegagalan ideologi ekonomi di dunia sebut saja liberalisme dan marxisme seharusnya menjadi titik tolak dari kembalinya penerapan ideologi yang khas dengan budaya Indonesia. Maka dari itu perlu sikap konsekuen untuk membangun ekonomi dengan sistem ekonomi Pancasila yang terejawantah dalam konstitusi Pasal 33 UUD 1945. Cabang produksi yang berhubungan dengan hajat hidup orang banyak dikuasasi oleh negara dan di peruntukkan pada sebesarbesarnya kesejahteraan rakyat. Inilah cita-cita Pancasila khususnya sila kelima, yaitu keadilan sosial bagi seluruh rakyat.
\end{abstract}

Kata Kunci : Ideologi Pancasila, Sistem Ekonomi, Pembangunan Hukum Ekonomi Indonesia. 


\begin{abstract}
Pancasila as a state ideology should be a catalyst in aspects of state life, especially in economic matters that are directly related to the interests of many people, in the 1945 Constitution article 33 it is clear that the article becomes the ideology of the Indonesian economic system, but in practice there is no clear instrument in carrying out this economic ideology, even many laws that contradict article 33 of the 1945 Constitution. even in its development the economic system adopted in Indonesia is influenced by external ideology, call it liberalism and communism, so this is a challenge for Pancasila in internalizing its values in the Inonomi system. therefore, it is necessary to reconstruct the ideology of Pancasila as the Indonesian economic system so that the ideals of Article 33 of the 1945 Constitution that is for the people's prosperity are truly realized. The purpose of this study is to review related to the Pancasila economic system for the realization of welfare. While this type of research is a normative research with a statutory approach and a concept approach.
\end{abstract}

Keyword : Pancasila Ideology, Economic System, Indonesian Economic Law Development. 


\section{PENDAHULUAN}

Negara indonesia merupakan negara besar dengan potensi alam yang relatif besar, dengan sumber daya kekayaan alam yang cukup besar tersebut negara indonesia menjadi ketertarikan tersendiri oleh negara-negara lain, hal ini terbukti sejarah mencatat bahwa datangnya imperialisme belanda awalnya adalah soal kekayaan alam indonesia, yaitu rempah rempah yang dikenal oleh VOC hingga akhirnya terbentuklah pemerintahan hindia belanda. Kekayaan alam selalu dipersandingkan dengan kemakmuran serta menjadi sektor penting bagi negaranegara berkembang. Namun dalam kenyataanya negara berkembang dengan kekayaan alam yang melimpah justru membawa malapetaka. Negara dengan sumberdaya alam yang melimpah sering kali terjerembab pada situasi yang dikenal dengan 'kutukan sumberdaya alam'.

Negara yang memiliki kekayaan alam yang melimpah akan sulit menjadi negara maju, hal ini sesuai pendapat Auty (1993) ilmuan sosial menurutnya ada fenomena menarik disebut sebagai "kutukan sumberdaya alam”. Negara-negara yang berkelimpahan dengan sumber daya alam seperti minyak dan gas, performa pembangunan ekonomi dan tata kelola pemerintahannya lebih buruk dibandingkan negara yang tidak memiliki SDA. Kondisi paradoksal ini sering kali membuat nalar rasio membantahnya, bukannya menjadi sektor penting dalam pembangunan negara malah menjadi hambatan dalam penataan pemerintahan yang baik. Bahkan anugerah seperti itu kerap kali menjadi penghambat daripada menciptakan pembangunan yang stabil dan berkelanjutan. ${ }^{2}$

Problem ekonomi merupakan suatu problem yang universal di mana seluruh dunia menaruh perhatian kepada masalah ini. Karena perhatiannya ini, sistem ekonomi menjadi maju dan berkembang dengan pesat. Perkembangan sistem ekonomi ini dengan segala kedahsyatan rekayasa teknologi tidak bisa dilepaskan dari peran dan kreatifitas teknokrat-teknokrat ekonomi kapitalisme. Dasar filosofi pemikiran ekonomi kapitalis ini bersumber dari tulisan Adam Smith dalam bukunya An Inquiry into the Nature and Causes of the Wealth of Nations

\footnotetext{
1 Macartan Humphreys, Jeffrey D. Sachs, and Joseph E. Stiglitz, Berkelit Dari Kutukan Sumberdaya Alam (Bogor: The Samdhana Institute, 2007). Hal ii

${ }^{2}$ Humphreys, Sachs, and Stiglitz. Hal. 1
} 
yang ditulis pada Tahun 1776 (Smith, 1937). Dalam bukunya ini Smith berpendapat bahwa: Produksi merupakan sumber utama kekayaan suatu negara, yaitu hasil kerjasama tenaga kerja manusia dan sumber-sumber daya. Dengan meningkatnya ketrampilan dan efisiensi para tenaga kerja maka kekayaan akan bertambah sejalan dengan persentase penduduk yang terlibat dalam proses produksi. $^{3}$

Dalam hal pengelolaan sumber daya alam, tidak terlepas dari ikut campur suatu negara lain, khususnya negara maju, yang menawarkan kerjasama dalam pengelolaan sumber daya alam. Sehingga untuk mengatur hal tersebut terbentuklah undang-undang yang terkait dengan itu, diantaranaya UndangUndang tentang penanaman modal asing. Politik hukum pengelolaan sumber daya alam, ada kecenderungan bahwa negara maju akan mengintervensi negara berkembang-dalam pengelolaan sumber alamnya dengan tujuan profit. Bagi negara yang tidak memiliki sistem ekonomi yang kuat maka akan mudah memberikan "karpet merah" bagi negara lain tersebut, bahkan kalau perlu langkah cepat dalam melakukan pembangunan lewat hutang. dengan adanya hutang negara yang banyak dengan alasan pembangunan apakah ini akan menggerus kedaulatan negara di mata asing. Sehinggga untuk mengatusi itu perlu hadirnya negara yang memiliki kedaulatan absolut terhadap wilayahnya, seperti yang tertuang dalam konstitusi diatas terkait fungsi negara dalam pengelolaan sumber kekayaan alamnya.

Adapun permasalahan yang akan diteliti, yaitu terkait dengan bagaimana konsep sistem ekonomi Pancasila untuk terwujudnya kesejahteraan, sumber daya alam yang ada ini merupakan karunia yang harus benar-benar dimanfaatkan secara tepat, hal ini sudah termaktub dalam Pasal 33 UUD 1945, yang berbunyi, kayaan alam yang dilaut, tanah, udara dikelola oleh negara untuk kesejateraan rakyat. Bunyi Konstitusi tersebut merupakan sinyalemen bahwa negara Indonesia merupakan negara yang menganut konsep negara kesejahteraan (welfare State). Maka dari itu perlu adanya sistem ekonomi sebagai acuan pembangunan ekonomi

\footnotetext{
${ }^{3}$ Ariza Fuadi, 'NEGARA KESEJAHTERAAN (WELFARE STATE) DALAM PANDANGAN ISLAM DAN KAPITALISME', Jurnal Ekonomi Syariah Indonesia, V.1 (2015).
} 
nasional sehingga pembangunan ekonomi bisa terarah dan juga menjadi manifeto kedaulatan negara dalam mengelola ekonomi nasional.

\section{METODE PENELITIAN}

Jenis penelitian ini bersifat deskriptis analisis, dengan menggunakan pendekatan perundang-undangan (statute approach) dan pendekatan konseptual (statute approach). statute approach yaitu aturan hukum yang menjadi fokus penelitian, sedangkan pengertian konsep yang relevan dalam hal ini adalah unsur abstraks dalam suatu bidang studi dan bersifat universal, fungsinya untuk memunculkan suatu yang menarik untuk dikaji ulang. ${ }^{4}$ Pengembangan konsep dalam penelitian hukum harus menggunakan paradigma konsepsional maupun kerangka teoritis. ${ }^{5}$

\section{PEMBAHASAN}

\section{A. DEOLOGI PANCASILA}

Ideologi menjadi penting bagi umat manusia karena hal tersebut dijadikan acuan dalam hal berfikir dan bertindak seseorang, seperti dalam ajarannya Destutt de Tracy seorang filsuf prancis bahwa manusia memiliki cita-cita dalam mengembangkan ilmu pengetahuan. setiap manusia dalam melakukan apapun pasti dipengaruhi oleh ideologinya, sebab ideologi dapat diartikan sebagai citacita. ${ }^{6}$ Ideologi menjadi istilah penting dalam pemikiran politik dan ekonomi Karl Marx, menurut Marx ideologi dikembangkan berdasar kepentingan golongan. Awalnya Marx menentang ideologi, namun akhirnya dia malah kejebak dan menggunakan ideologi dalam ajarannya.

\footnotetext{
${ }^{4}$ Johnny Ibrahim, Teori Metodelogi Penelitian Hukum Normatif, ed. by Sutiyono Wahyudi, kedua (Malang: Bayumedia Publishing, 2006). Hal. 202

${ }^{5}$ Soerjono Soekanto and Sri Mamudji, Penelitian Hukum Normatif Suatu Tinjauan Singkat, 1st edn (Jakarta, 1985). Hal. 10

${ }^{6}$ HBM. Munir, Umi Salamah, and Suratman, PENDIDIKAN PANCASILA, 3rd edn (Malang: Madina Media, 2016). Hal. 52
} 
Pancasila merupakan ideologi bangsa indonesia, artinya dalam berfikir dan bertindak bangsa indonesia harusnya dipengaruhi oleh ideologi pancasila, atau sesuai dengan nilai-nilai pancasila, dengan begitu pancasila seharusnya menjadi weltanchau bagi kehidupan bernegara, suatu ideologi memiliki ciri atau pembeda dengan ideologi yang lainnya, ideologi Pancasila menurut Soekarno bukanlah ideologi liberal dan juga bukan ideologi Komunis, ideologi pancasila bersumber dari nilai-nilai luhur bangsa Indonesia yang hidup sejak dulu. ${ }^{7}$

Pancasila sebagai ideologi akan menjelma menjadi sistem hukum, sistem ekonomi serta sistem sosial di indonesia, ideologi Pancasila merupakan ajaran atau doktrin tentang cita-cita bangsa Indonesia yang diyakini kebenarannya oleh bangsa indonesia. Sebagaimana termaktub dalam Pembukaan UUD 1945, pancasila memenuhi syarat untuk disebut sebagai sebuah ideologi. Pancasila harus disebutkan sebagai bintang pemandu arah (leitztern) kebijakan pembaharuan hukum di Indonesia. Kebijakan pembaharuan yang tidak menyinggung apa yang menjadi dasar penentu arah kebijakan pembangunan hukum, yakni Pancasila dapat dikatakan masih bersifat parsial karena kurang melihat sisi pembangunan hukum nasional secara integral yang seharusnya melibatkan pembicaraan tentang Pancasila sebagai bintang pemandu arah (leitztern). ${ }^{8}$

\section{B. NEGARA KESEJAHTERAAN (WELFARE STATE)}

Negara Kesejahteraan (Welfare State) menurut Naqvi (2003) pertama kali digaungkan dalam bahasa Inggris pada tahun 1941 untuk mencapai keseimbangan antara kekuatan negara dan kebebasan individu. Negara Welfare State merupakan ide tentang negara sebagai pelayan warga negara sehingga tercapai kesejahteraan. Menurut Pass dan Lowes negara kesejahteraan ini dapat dimaknai sebagai suatu negara yang memberikan perhatian lebih pada kesejahteraan rakyatnya yaitu dengan suatu kebijakan jaminan sosial (pendidikan, kesehatan, sosial), tunjangan sakit dan pengangguran dst. Menurut Husodo (2006) Negara kesejahteraan

\footnotetext{
${ }^{7}$ Munir, Salamah, and Suratman. Hal. 59

8 Siti Malikhatun Badriyah, Penemuan Hukum Dalam Konteks Pencarian Keadilan, 1st edn (Semarang: Badan Penerbit Universitas Diponegoro, 2010). Hal. 45
} 
adalah negara dianggap bertanggung jawab menjamin standar kesejahteraan hidup minimum bagi setiap warga negaranya Negara. ${ }^{9}$

Ide welfare state di Eropa Barat merupakan anti thesa dari ide Liberal, dimana pada saat itu liberalisme dianggap gagal dalam memberikan kesejahteraan pada rakyat. welfare state tidak dapat dilepaskan dari perjuangan kaum buruh. Perjuangan buruh untuk mendapatkan hak-hak dasar yang selama ini hanya dinikmati oleh sekelompok borjuis yang memiliki alat produksi. Dalam tulisannya Edi Suharto menjelaskan bahwa pertama-tama negara kesejahteraan dipraktekkan di Eropa dan Amerika Serikat pada abad XIX yang ditujukan untuk mengubah kapitalisme-liberalisme menjadi emansipatori dan lebih manusiawi. ${ }^{10}$

Kemudian Esping-Andersen berpendapat bahwa negara kesejahteraan bukanlah suatu konsep kaku. Menurut Triwibowo dan Bahagijo (2006) terdapat empat pilar utama negara kesejahteraan yaitu: 1) social citizenship; 2) full democracy; 3) modern industrian relation systems; serta 4) rights to education and the expansion of modern mass education systems. Dengan syarat-syarat ekonomi, sosial dan politik tersebut di atas, tidak semua negara dengan penduduk yang berpendapatan tinggi tidak dapat dianggap sebagai negara kesejahteraan. ${ }^{11}$

\section{SISTEM EKONOMI INDONESIA}

Sistem ekonomi adalah acuan atau kerangka acuan negara dalam melakukan pembangunan ekonomi. sistem ekonomi penting untuk dijadikan arah bagi negara dalam mengambil kebijakan kegiatan ekonomi nasional. Ada pun sistem ekonomi yang terkenal dan banyak dianut oleh negara-negara di dunia ada empat sistem ekonomi, yaitu: sistem ekonomi terencana (planned economic system), sistem ekonomi kapitalis (market economic system), sistem ekonomi campuran (mixed economic system), dan sistem ekonomi Islam (Islamic economic system). ${ }^{12}$

\footnotetext{
${ }^{9}$ Fuadi.

${ }^{10}$ Fuadi.

${ }^{11}$ Fuadi.

${ }^{12}$ Candra Irawan, DASAR-SASAR PEMIKIRAN HUKUM EKONOMI INDONESIA, Mandar Maju, $2012<$ https://doi.org/10.1017/CBO9781107415324.004>. Hal. 34
} 
Sistem Ekonomi yang direncanakan merupakan sistem ekonomi dilakukan dengan perencanaan oleh pemerintah. Negara wajib merumuskan perencanaan ekonomi secara lebih komprehensif dan dapat mengoptimalisasikan produksi dan investasi untuk kemajuan negara. ${ }^{13}$ Adapun Sistem ekonomi campuran adalah perpaduan sistem perekonomian pasar dan terencana. sistem ekonomi liberal menitik beratkan pada hak property yaitu seorang individu boleh memiliki semua faktor produksi, sedangkan sistem komunis semua faktor produksi dikuasai pemerintah. ${ }^{14}$ Adapun Sistem ekonomi Islam yaitu sistem ekonomi yang didasarkan pada nilai-nilai Islam. ${ }^{15}$ Sistem ekonomi islam relatif lebih baru dibandingkan sistem ekonomi pendahulunya, namun ekonomi Islam diyakini akan terus berkembang, dengan berpijak pada prinsip dasar agama, kesejahteraan (welfare) yang menjadi tujuan ekonomi akan dapat terwujud. ${ }^{16}$

Ditengah gempuran berbagai macam aliran ideologi ekonomi, Indonesia juga mengalaminya, bahkan dipengaruhi oleh ideologi luar yang bukan jati diri ideologi indonesia dalam pembangunan ekonomi. Menurut Emil Salim sebagaimana dikutip oleh Dawam Raharjo bahwa sistem ekonomi Indonesia bergerak dari kiri dan kekanan, awalnya cenderung sosialis, namun dalam perkembangannya berbalik ke kanan yaitu berkiblat pada liberal. Kemudian setelah Orde Baru diusahakan untuk diseimbangkan, kemudian sampai pada titik keseimbangan menjadi Sistem Ekonomi Pancasila. ${ }^{17}$ Artinya dalam implementasinya sistem ekonomi sudah ada di konstitusi negara, selama ini masih minim dialektika tentang sistem ekonomi pancasila yang sudah ada dalam konstitusi. Konstitusi ekonomi merupakan istilah yang relatif baru, negara yang pertama kali menuangkan sistem ekonomi dalam konstitusi negara adalah ini Soviet pada Tahun 1918. Franz Bohn yang meletakkan landasan teoritis tentang konsep konstitusi ekonomi. ${ }^{18}$

\footnotetext{
${ }^{13}$ Irawan. Hal. 39

14 Irawan. hal. 1

${ }^{15}$ Irawan. Hal. 42

${ }^{16}$ Mohammad Zaki Su'aidi, 'Pemikiran m. Umer Chapra Tentang Masa Depan Ekonomi Islam', Ishraqi, 10.1 (2012), 1-19.

${ }^{17}$ M. Dawam Rahardjo, 'Menuju Sistem Perekonomian Indonesia', Unisia, 32.72 (2009), 113-28 <https://doi.org/10.20885/unisia.vol32.iss72.art1>.

18 Jimly Asshiddiqie, 'MEMPERKENALKAN GAGASAN KONSTITUSI EKONOMI', Jurnal Hukum Prioris, 3.2 (2013), 1-26.
} 
Dalam pandangan Manuel Kaisiepo yang dikutip oleh Petrus C.K.L. Bello pancasila sebagai ideologi akan sulit menjangkau persoalan yang konkrit seperti ekonomi, pancasila secara metodologis sangat lemah dibandingkan dengan sosialisme dan liberalisme. ${ }^{19}$ Pendapat Manuel diatas tidak sepenuhnya benar, sebab idologi pancasila secara metodologi sangatlah kuat bahkan pancasila bisa menjadi sistem filsafat, secara ontologis nilai pancasila berasal dari karakter bangsa indonesia yang digali oleh para founding father. Adapun epistemologi pancasila adalah prismatik, artinya kebenaran perspektif pancasila merupakan kebenaran yang akomudatif, dan juga pada akhirnya mengakui kebenaran konsensus. Terakhir aksiologi, pancasila dalam sila kelima menjadi nilai aksiologis bahwa tujuan dari pancasila adalah mewujudkan kesejahteraan.

Jika menelaah sistem Perekonomian Nasional berdasarkan konstitusi, dapat merujuk pada Pasal 33 UUD 1945, yang berbunyi: (1) Perekonomian menjadi usaha bersama berdasar atas asas kekeluargaan. (2) Cabang produksi yang berhubungan langsung dengan hajat hidup orang banyak dikuasai oleh negara. (3) Sumber Daya Alam dikuasai oleh Negara untuk kemakmuran rakyat. (4) Sistem ekonomi menganut sistem ekonomi Pancasila. Sistem ekonomi Pancasila mulai diketengahkan oleh Mubyarto dan koleganya di Fakultas Ekonomi Universitas Gajah Mada (UGM) hal ini sebagai respon dari sistem ekonomi kapitalis dan sistem ekonomi terencana yang selama ini diterapkan di Indonesia yang ternyata tidak mampu mewujudkan cita-cita negara. ${ }^{20}$ Pada tahun 1980, sejumlah ekonom menyempurnakan gagasan itu menjadi konsep Ekonomi Pancasila (EP). Pada waktu itu ditambahkan konsep-konsep epistemologi dan aksiologi, terutama oleh Dr. Sarino Mangunpranoto. Sumbangan pemikiran lain datang dari Prof. Sri-Edi Swasono dengan pemikiran-pemiklran strukturalisme, walaupun banyak menggunakan istilah "Demokrasi Ekonomi". ${ }^{21}$

Maka dapat dikatakan Indonesia tidak menganut sistem ekonomi kapitalis atau sistem ekonomi terencana atau sistem ekonomi islam, tetapi lebih mengakomodasikan berbagai sistem ekonomi tersebut dengan penekanan pada

\footnotetext{
${ }^{19}$ Petrus C.K.L.Bello, Ideologi Hukum Refleksi Filsafat Atas Ideologi Di Balik Hukum, Pertama (Bogor: Insan Merdeka, 2013). Hal. 119

${ }^{20}$ Irawan. Hal. 46

${ }^{21}$ M Dawam Rahardjo, 'Isu-Isu Kontemporer Ekonomi Pancasila', UNISIA, 27.53 (2004), 207-17.
} 
sistem ekonomi terencana karena pemerintah diberikan ruang lebih luas untuk mengatur perekonomian untuk mencapai kesejahteraan rakyat. ${ }^{22}$

Menurut RM.AB. Kusuma, Apa yang dimaksud "penting bagi negara..." adalah cabang-cabang produksi strategis, sedangkan "dikuasai" diinterpretasi bahwa "dikuasai oleh negara tidak berarti negara sendiri menjadi pengusaha, usahawan atau ondenemer. ${ }^{23}$ Mahkamah telah memberi makna mengenai penguasaan negara dalam Pasal 33 UUD 1945, sebagaimana telah dipertimbangkan dalam Putusan Mahkamah Konstitusi (MK) Nomor 002/PUUI/2003, tanggal 21 Desember 2004 mengenai pengujian Undang-Undang Migas, yang menyatakan bahwa, ${ }^{24}$ "Arti penguasaan oleh negara dalam Pasal 33 UUD 1945 lebih tinggi atau lebih luas daripada pemilikan dalam konsepsi hukum perdata. Konsep ini berkaitan dengan kedaulatan rakyat”. Lebih lanjut Mahkamah Konstitusi menginterpretasi penguasaan pada Pasal 33 UndangUndang Dasar adalah; pertama Pengaturan. Kedua, Pengelolaan. Ketiga, Kebijakan keempat, Pengurusan. Kelima, Pengawasan. ${ }^{25}$

Hak penguasaan negara dalam pasal diatas memiliki konsekuensi logis bahwa negara sebagai pengatur dan penjamin kesejahteraan rakyat. Bidang usaha atas sumber daya alam harus diatur dan dilakukan pengawasan khusus. Karena hal tersebut menyangkut hajat hidup orang banyak. Hak pengusaan negara dalam pasal 33 UUD 1945 secara ekplisit negara mengusahakan pengelolaan sumber daya alam yang berkaitan dengan pelayanan publik dengan asas kekeluargaan, kepentingan umum dan mencegah terjadinya monopoli dan oligarki. ${ }^{26}$ Sri-Edi Swasono menegaskan bahwa Pasal 33 Ayat (1) Undang-Undang Dasar 1945 mengandung arti sebagai asas kekeluargaan Usaha bersama, artinya paham

\footnotetext{
${ }^{22}$ Irawan. Hal. 45

23 Elli Ruslina, 'Makna Pasal 33 Undang-Undang Dasar 1945 Dalam Pembangunan Hukum Ekonomi Indonesia', Jurnal Konstitusi, 9.1 (2012).

${ }^{24}$ Habib Shulton Asnawi, 'Politik Hukum Putusan MK Nomor Mengembalikan Kedaulatan Negara Dan Perlindungan HAM Legal Policy of Constitutional Court', Jurnal Konstitusi, 13.2 (2016), 300-320.

${ }^{25}$ Yance Arizona, 'Perkembangan Konstitusionalitas Penguasaan Negara Atas Sumber Daya Alam Dalam Putusan Mahkamah Konstitusi', Jurnal Konstitusi, 8.3 (2011), 257-314 <https://www.neliti.com/publications/111506/perkembangan-konstitusionalitas-penguasaannegara-atas-sumber-daya-alam-dalam-pu>.

${ }^{26}$ J. Ronald Mawuntu, 'Konsep Penguasaan Negara Berdasarkan Pasal 33 UUD 1945 Dan Putusan Mahkamah Konstitusi', Fakultas Hukum Unsrat, XX.3 (2012), 86-95 <https://doi.org/10.1016/j.actamat.2007.11.013>.
} 
komunitarianisme ditempatkan sebagai tujuan utama serta mengarusutamakan kemakmuran masyarakat. ${ }^{27}$ Dengan ini dapat disimpulkan bahwa demokrasi ekonomi identik dengan mengedepankan kepentingan masyarakat dari kepentingan individu.

Mohammad Hatta mengatakan bahwa dasar perekonomian di masa datang akan semakin jauh dari dasar individualisme dan semakin dekat dengan kolektivisme, yaitu sama sejahtera. ${ }^{28}$ Lebih lanjut M. Hatta mengatakan bahwa Sistem ekonomi inilah yang seharusnya diterapkan oleh Indonesia, kalau saja konsekuen terhadap sistem ekonomi nasional dalam UUD 1945 maka akan mengalahkan sistem ekonomi kapitalis. Maka dapat disimpulkan bahwa sistem ekonomi yang dianut oleh indonesia yaitu sistem ekonomi campuran, tetapi lebih condong kepada sistem ekonomi terencana karena peran negara cukup besar dalam mengatur perekonomian. ${ }^{29}$. Hal senada juga disampaikan oleh Herman Soewardi bahwa yang dituju adalah suatu sistem ekonomi tertentu, yang bukan ekonomi kapitalistik namun suatu sistem ekonomi berdasar kebersamaan dan berdasar atas asas kekeluargaan, menurut Sofian Effendi asas kekeluargaan menjadi landasan filosofis dalam Pembukaan Undang Undang Dasar 1945. Semangat kekeluargaan merupakan corak budaya bangsa Indonesia, inilah kekuatan bangsa dan negara Indonesia. Namun kalau implementasi kontraproduktif yaitu mengedepankan nilai yang bersifat individualistik Undang Undang Dasar itu pasti tidak ada gunanya". ${ }^{30}$

Dari uraian diatas banyak yang mengatakan bahwa indonesia memiliki konsep ekonomi sendiri yang khas yaitu tertuang dalam Pasal 33 UUD Tahun 1945, juga ada yang mengatakan bahwa sistem ekonomi Indonesia merever pada nilai-nilai Pancasila kalau di peras menjadi sistem ekonomi gotong-royong. Akan tetapi dalam implementasinya sistem ekonomi pancasila tidak memiliki instrumen

\footnotetext{
${ }^{27}$ Ruslina.

${ }^{28}$ Irawan. Hal. 45

${ }^{29}$ Irawan. Hal. 46

${ }^{30}$ Ruslina.
} 
yang praktis, sehingga ketika dikritisi hampir tidak ada praktik ekonomi yang dijalankan dan sesuai dengan nilai-nilai Pancasila. ${ }^{31}$

\section{PERAN PEMBANGUNAN EKONOMI UNTUK MENINGKATKAN KESEJAHTERAAN}

Ideologi kapitalisme adalah pemikiran Adam Smith (1776) melalui bukunya yang sangat terkenal "An Inquiry into the Nature and Causes of the Wealth of Nations. ${ }^{32}$ Sistem ekonomi kapitalis memberikan kebebasan kepemilikan oleh swasta terhadap modal dan sumber daya atau sumber-sumber produksi. Kegiatan ekonomi bersandar pada persaingan bebas diantara pelaku ekonomi. Negara tidak terlalu mencampuri urusan perekonomian. Penentuan harga komoditas ditentukan oleh mekanisme penawaran dan permintaan (supply and demand). Meskipun negara turut serta, namun keterlibatan negara diupayakan seminimal mungkin (liberalisme). Artinya negara hanya menjadi penjaga malam tidak boleh negara terlalu ikut campur lebih dalam terkait dengan urusan rakyatnya, yang penting negara menjamin keamanan dan ketertiban negara, urusan ekonomi diserahkan pada pasar (market). Sistem kapitalis sangat mengagungkan produksi sebagai kekuatan dalam menentukan kompetisi sehingga para produsen yang paling unggul akan bertahan hidup, sedangkan yang lemah dan tidak mampu bersaing akan tersingkir.

Adapun Paradigma kapitalisme antara lain adalah (1) laissez-faire, yaitu keterlibatan negara dalam kegiatan ekonomi terbatas, pasar yang lebih dominan. (2) ekonomi pasar diletakkan di atas persaingan bebas dan persaingan sempurna. (3) full employment, yaitu ekonomi akan berjalan baik jika tanpa intervensi pemerintah. (4) memenuhi kepentingan individu juga berarti memenuhi kepentingan masyarakat (harmony of interest). (5) menitikberatkan kegiatan ekonomi pada industri. (6) hukum ekonomi berlaku secara universal. (7) perhatiannya terutama pada sisi pertumbuhan ekonomi. ${ }^{33}$ Adapun sifat

\footnotetext{
${ }^{31}$ Kwik Kian Gie, NASIB RAKYAT INDONESIA Dalam Era Kemerdekaan, ed. by Andi Tarigan (Jakarta: PT Gramedia Pustaka Utama, 2016). Hal. 46

${ }^{32}$ Irawan. Hal. 35

${ }^{33}$ Irawan. Hal. 37
} 
kapitalisme telah melahirkan beberapa ciri yang kontraproduktif seperti: Menolak nilai-nilai akidah, syariat dan akhlak yang mulia, dan pengambilan bunga, Faktorfaktor ekonomi dikuasai dan didominasi oleh setiap individu. Kapitalisme identik dengan monopoli karena kecenderungan pemodal untuk menguasai segalanya dan menghapuskan semua persaingan dengannya. ${ }^{34}$ Sedangkan ideologi marxisme merupakan antithesa dari liberalisme, dan marxisme menetang ajaran liberalisme karna tidak mampu memberi jalan keluar terhadap keberpihakan pada rakyat, khususnya kaum proletar.

Kedua terus 'bersitegang', adanya dialektika ideologi liberalisme Adam Smith yang di anut oleh Eropa Barat, dan Ideologi Marxisme yaitu Uni Sovyet, Negara Eropa Timur, China, Korea Utara, Kuba, akan tetapi setelah beberapa dekade dua ideologi besar tersebut gagal, yang adalah sintesis antara dua sistem tersebut dengan kadar yang berbeda, apakah sistem ekonomi tersebut cenderung liberal ataukah dominan Marxisnya. ${ }^{35}$ Hal ini senada dengan pendapat Griffin, bahwa negara-negara di dunia dalam mengimplementasikan ideologi ekonominya, tidak ada yang konsekuen benar-benar menerapkan perekonomian pasar bebas bahkan negara Amerika Serikat sekalipun. ${ }^{36}$ Begitu juga dengan negara ideologi marxis, tidak konsekuen mengimplementasikan ideologinya secara murni, ideologi yang diterapkan dan yang dijadikan sistem ekonomi mengalami 'singkritisme ideologi.

Dari kegagalan kedua ideologi tersebut seharusnya indonesia mempertegas bahwa sistem ekonomi negaranya adalah sistem ekonomi Pancasila. Sebagaimana uraian diatas, hakikat dari Pasal 33 UUD 1945 merupakan pandangan bahwa negara harus hadir dan dirasakan keberadaannya oleh rakyat. Bahkan menurut David Straker Negara dianalogikan sebagai korporasi memberikan jaminan mutu hidup yang berkualitas kepada rakyat yang multi perspektifnya. ${ }^{37}$ Namun tujuan negara kesejahteraan ini tidak lantas mulus sesuai dengan cita-cita yang agung serta seirama dengan nilai kemanusiaan. Faktor ekonomi global akan

\footnotetext{
${ }^{34}$ Fuadi.

${ }^{35}$ Gie. Hal. 47

${ }^{36}$ Irawan. Hal. 41

37 Suparto Wijoyo, 'Tata Kelola Pertambangan Dalam Kerangka Indonesia Incorporated Untuk Mewujudkan Negara Kesejahteraan', Jurnal Hukum Lingkungan, 4.1 (2017), 1-30 <http://www.jhli.icel.or.id/index.php/jhli/article/view/47>.
} 
mempengaruhi praktik kebijakan negara kesejahteraan, misalnya Persoalan krisis ekonomi global, kemiskinan, pengangguran. Konsep negara kesejahteraan bisa menemui kegagalan serta tidak bisa mengantarkan manusia pada kesejahteraan, keadilan, kedamaian, dan kesejahteraan bersama dalam kehidupan. ${ }^{38}$

Bjorn Hettne mempertanyakan peran negara dan pemerintah untuk mensejahterakan rakyat harus ditata kembali dengan menyodorkan Paradigma Theory \& Policy Making dalam lingkup Good Corporate Governance. ${ }^{39}$ Menurut Jurgen Habermas negara kesejahteraan justru memiliki kelemahan yang sangat urgen, pertama karena negara kesejahteraan mengupayaan kesejateraan umum maka dimungkinkan negara akan melakukan apapun sehingga akan cenderung jatuh pada totaliter. Kedua, negara kesejahteraan itu berangkat dari pengandaian senasib sepenanggungan yang pada akhirnya akan menciptakan kondisi sosial yang tidak tangguh karna menggantungkan semua kebutuhannya pada negara. ${ }^{40}$

Realitas diatas berbanding terbalik dengan potensi yang dimiliki oleh Indonesia, bahkan ada teori "kutukan sumber daya alam" artinya negara yang kaya akan sumber daya alam akan menemui beberapa masaalah dalam pemerintahannya. Misalnya dalam hal manajemen kekayaan sumber alam dan pembangunan ekonomi jangka panjang, ternyata performa sejumlah negara kaya sumber daya alam ada yang lebih baik dibandingkan negara yang berciri sama. Menurut Ross (2003) Indonesia dan Nigeria memiliki pendapatan per kapita yang seimbang dan sama-sama sangat bergantung pada penjualan minyak. Namun sekarang, pendapatan per kapita Indonesia ternyata empat kali lebih besar dibandingkan Nigeria. ${ }^{41}$ Banyak negara kaya minyak mengalami penurunan dalam pendapatan per kapita antara periode 1970 dan 2000, dan sebagian kecil jatuh terjerembab ke dalam krisis utang mendalam. Kutukan itu-bahwa pendapatan minyak seringkali tidak diwujudkan dalam pembangunan jangka panjang-bukanlah persoalan takdir. Minyak dapat menjadi awal dari pertumbuhan. ${ }^{42}$

\footnotetext{
${ }^{38}$ Fuadi.

${ }^{39}$ Wijoyo.

${ }^{40}$ C.K.L.Bello. hal. 142-143

${ }^{41}$ Humphreys, Sachs, and Stiglitz. Hal. 2

${ }^{42}$ Humphreys, Sachs, and Stiglitz. Hal. 202
} 
Kekuasaan negara atas sumber daya alam bersumber dari rakyat yang dikenal dengan bangsa, yang kepadanya diberikan wewenang atau kekuasaan untuk mengatur, mengurus, memelihara, dan mengawasi pemanfaatan seluruh potensi sumber daya alam yang ada di seluruh wilayah Indonesia. Kemudian komponen penting yang harus menjadi fondasi pembangunan landasan hukum dan politik pengelolaan sumber daya alam Migas/Minerba Nasional yang menceminkan hak menguasai oleh Negara atas sumber daya alam Migas/Minerba untuk terwujudnya kedaulatan nasional adalah: a) Kepemilikan Kekayaan Alam; b) Penguasaan Oleh Negara; c) Kewenangan Perusahaan Negara dalam pengusahaan Migas/Minerba sampai kepada prinsip kerjasama dengan pihak ketiga. ${ }^{43}$ Hak menguasai cabang produksi benar-benar digunakan untuk sebesarbesarnya kemakmuran rakyat. Konsep hak menguasai negara sebenarnya berasal dari hukum adat. ${ }^{44}$ Ini adalah sesuai dengan budaya dan konsep Pancasila, sebab pada dasarnya Pancasila berasal dari kebudayaan dan adat yang telah lama hidup dan berkembang ditengah masyarakat.

Konsep sistem ekonomi pancasila atau sistem ekonomi indonesia seharusnya menjadi dasar aturan hukum yang berhubungan dengan cabang produksi sumber daya alam, secara eksplisit Pasal 33 UUD 1945 mengandung arti negara menguasai cabang produksi, dan MK telah menginterpretasikan maksud dari mengusai. Artinya dari penguasaan negara terhadap cabang produksi SDA lebih luas dari sekedar memiliki. Diantara lima tafsir dari MK adalah negara berwenang mengawasi pelaksaan dari kegiatan produksi sumber daya alam, artinya dalam mengawasi tentunya negara juga diberikan kewenangan untuk mengevaluasi. Sehingga dari sini negara berhak melakukan tindakan terhadap swasta atau BUMN berdasar dari hasil pengawasannya. Dengan penerapan seperti itu kedaulatan dan kewibawaan negara semakin berjaya dan inilah sesungguhnya makna dari sistem ekonomi Pancasila.

\footnotetext{
${ }^{43}$ Kuswandi.

44 Afifah Kusumadara, 'Perkembangan Hak Negara Atas Tanah: Hak Menguasai Atau Hak', Fakultas Hukum Brawijaya, 20.2 (2013), 262-76.
} 


\section{KESIMPULAN}

Mengetengahkan sistem ekonomi pancasila menjadi keharusan ditengah pembangunan ekonomi yang tidak tentu, kegagalan ideologi ekonomi di dunia sebut saja liberalisme dan marxisme seharusnya menjadi titik tolak dari kembalinya penerapan ideologi yang khas dengan budaya indonesia, yaitu Pancasila kalau disarikan lagi gotong royong, namun ada kendala dalam penerapan ideologi pancasila yaitu belum memiliki instrumen yang jelas, bahkan hari ini penerapan ideologi pancasila masih dibayang-bayang oleh narasi ideologi besar dunia, sehingga cita-cita yang mau dicapai oleh pancasila urung sampai.

Maka dari itu perlu sikap konsekuen dari semua pihak untuk membangun ekonomi dengan sistem ekonomi pancasila yang tersarikan dalam konstitusi Pasal 33 UUD 1945. Cabang produksi yang berhubungan dengan hajat hidup orang banyak dikuasasi oleh negara dan di peruntukkan pada sebesar-besarnya kesejahteraan rakyat. Inilah cita-cita pancasila khususnya sila kelima, yaitu keadilan sosial bagi seluruh rakyat. 


\section{DAFTAR PUSTAKA}

\section{BUKU}

Assidiqie, Jimly, Pokok-Pokok Hukum Tata Negara Indonesia, (Jakarta: Bhuana Ilmu Populer, 2007)

Badriyah, Siti Malikhatun, Penemuan Hukum Dalam Konteks Pencarian Keadilan, 1st edn (Semarang: Badan Penerbit Universitas Diponegoro, 2010)

C.K.L.Bello, Petrus, Ideologi Hukum Refleksi Filsafat Atas Ideologi Di Balik Hukum, Pertama (Bogor: Insan Merdeka, 2013)

Gie, Kwik Kian, NASIB RAKYAT INDONESIA Dalam Era Kemerdekaan, ed. by Andi Tarigan (Jakarta: PT Gramedia Pustaka Utama, 2016)

Humphreys, Macartan, Jeffrey D. Sachs, and Joseph E. Stiglitz, Berkelit Dari Kutukan Sumberdaya Alam (Bogor: The Samdhana Institute, 2007)

Ibrahim, Johnny, Teori Metodelogi Penelitian Hukum Normatif, ed. by Sutiyono Wahyudi, kedua (Malang: Bayumedia Publishing, 2006)

Munir, HBM., Umi Salamah, and Suratman, PENDIDIKAN PANCASILA, 3rd edn (Malang: Madina Media, 2016)

Soekanto, Soerjono, and Sri Mamudji, Penelitian Hukum Normatif Suatu Tinjauan Singkat, 1st edn (Jakarta, 1985)

\section{JURNAL}

Arizona, Yance, 'Perkembangan Konstitusionalitas Penguasaan Negara Atas Sumber Daya Alam Dalam Putusan Mahkamah Konstitusi', Jurnal $\begin{array}{llll}\text { Konstitusi, } & 8.3 & \text { (2011), }\end{array}$ <https://www.neliti.com/publications/111506/perkembangankonstitusionalitas-penguasaan-negara-atas-sumber-daya-alam-dalam-pu> Asnawi, Habib Shulton, 'Politik Hukum Putusan MK Nomor Mengembalikan Kedaulatan Negara Dan Perlindungan HAM Legal Policy of Constitutional Court', Jurnal Konstitusi, 13.2 (2016), 300-320 
Asshiddiqie, Jimly, 'MEMPERKENALKAN GAGASAN KONSTITUSI EKONOMI', Jurnal Hukum Prioris, 3.2 (2013), 1-26

Fuadi, Ariza, 'NEGARA KESEJAHTERAAN (WELFARE STATE) DALAM PANDANGAN ISLAM DAN KAPITALISME', Jurnal Ekonomi Syariah Indonesia, V.1 (2015)

Gunawan, Mohammad SIgit, 'REKONSTRUKSI NEGARA HUKUM PANCASILA DALAM PENYELENGGARAAN KEKUASAAN DI INDONESIA BERDASARKAN UUD 1945', Syntax Literate, 3.4 (2018), 58-69 <https://doi.org/10.1590/s1809-98232013000400007>

Irawan, Candra, DASAR-SASAR PEMIKIRAN HUKUM EKONOMI INDONESIA, Mandar Maju, 2012 <https://doi.org/10.1017/CBO9781107415324.004>

Kusumadara, Afifah, 'Perkembangan Hak Negara Atas Tanah : Hak Menguasai Atau Hak', Fakultas Hukum Brawijaya, 20.2 (2013), 262-76

Kuswandi, 'MODEL PENGELOLAAN SUMBER DAYA ALAM UNTUK SEBESAR- BESARNYA KEMAKMURAN RAKYAT', Jurnal Hukum Mimbar Justitia, 1.2 (2015), 518-31

Mawuntu, J. Ronald, 'Konsep Penguasaan Negara Berdasarkan Pasal 33 UUD 1945 Dan Putusan Mahkamah Konstitusi', Fakultas Hukum Unsrat, XX.3 (2012), 86-95 <https://doi.org/10.1016/j.actamat.2007.11.013>

Rahardjo, M. Dawam, 'Menuju Sistem Perekonomian Indonesia', Unisia, 32.72 (2009), 113-28<https://doi.org/10.20885/unisia.vol32.iss72.art1>

Rahardjo, M Dawam, 'Isu-Isu Kontemporer Ekonomi Pancasila', UNISIA, 27.53 (2004), 207-17

Ruslina, Elli, 'Makna Pasal 33 Undang-Undang Dasar 1945 Dalam Pembangunan Hukum Ekonomi Indonesia’, Jurnal Konstitusi, 9.1 (2012)

Su'aidi, Mohammad Zaki, 'Pemikiran m. Umer Chapra Tentang Masa Depan Ekonomi Islam', Ishraqi, 10.1 (2012), 1-19

Syahrin, Muhammad Alvi, 'Menakar Kedaulatan Negara Dalam Perspektif Keimigrasian', Jurnal Penelitian Hukum De Jure, 18.1 (2018), 43 
<https://doi.org/10.30641/dejure.2018.v18.43-57>

Wijoyo, Suparto, 'Tata Kelola Pertambangan Dalam Kerangka Indonesia Incorporated Untuk Mewujudkan Negara Kesejahteraan', Jurnal Hukum Lingkungan, $\quad 4.1 \quad$ (2017), 1-30 <http://www.jhli.icel.or.id/index.php/jhli/article/view/47> 